\title{
LISCANO: EL PEZ, EL TOPO
}

POR

Rafael ArRáiz Lucca

Aunque la imagen pública de Juan Liscano puede situarlo en los campos dionisíacos, buena parte de su obra poética está construida sobre la base de la razón, de las estructuras casi simétricas, de la pretensión de armar un cuerpo complejo y cerrado sobre sí mismo. Quienes ven en Liscano a un frenético indagador en los resortes de eros sobre los que se apoya la cultura occidental y oriental se sorprenderían con la arquitectura de los libros Nuevo mundo Orinoco, Fundaciones, El viaje, Myesis y Domicilios. En ellos se manifiesta claramente el propósito de construir grandes cuerpos coherentes, articulados.

Pero esta vigorosa vocación arquitectónica de Liscano en nada lo aleja (por el contrario) del ineludible batallar con sus obsesiones. Por supuesto, en una vida larga y fructífera como pocas, las obsesiones han sido muchas, variadas y hasta valientemente contradictorias. Entre ellas lo americano ocupó un lugar central en un pasaje dilatado de su trayectoria poética. También se detuvo con fruición y sigue haciéndolo en el desierto del apocalipsis. La destrucción del planeta (por superpoblación, por contaminación) es una de sus angustias centrales que, sospecho, se asienta más en una crítica al modelo de vida del hombre sobre la tierra que, exclusivamente, en un grito ecológico. Además, en la maleta de persistencias figura con un lugar estelar lo que podríamos llamar la imposibilidad del acoplamiento amoroso. El desencuentro, la fatalidad a la que está condenado todo esfuerzo por conciliar los contrarios que forman pareja. Y es hija de esta constatación la operación que surge a lo largo de casi toda su obra; me refiero al juego de los contrarios, a la batalla que ocurre sin tregua entre todo lo que se disponga al diálogo. La cópula, según Liscano, es el único momento donde cesa el combate, donde el hombre sale de su propio infierno, de su historia.

Sin embargo, es a partir de Espiritualidad y literatura: una relación tormentosa cuando el afán por resolver en el poema la contienda cesa. A partir de la constatación de esta imposibilidad, su poesía toma un rumbo menos implorante, no menos angustioso, pero sí sin la esperanza de resolver la lucha de los contrarios en el poema. Pero esta aceptación en ningún caso puede tenerse como un abandono. De sus obsesiones, como si se tratara de su sombra, Liscano no ha podido librarse.

La insistencia por fijar los contornos de eros no es sólo expresión, como podría pensarse, de un deleite sensual, es que en ese mapa el poeta halla respuesta a las tensiones de sus relaciones afectivas. Bien sea la relación madre-hijo o la de pareja. 
La enumeración de intereses que concatené en líneas anteriores nos habla de una riqueza afianzada en, por lo menos, dos columnas: la intensidad de sus obsesiones y la variedad de las mismas. Su poesía esgrime la riqueza de quien ha podido ser muchos hombres en una vida agitadísima. La multiplicidad de su obra más que debilitarla lo que hace es enriquecerla porque todo lo ha asumido apasionadamente, bien sea como arquitecto o como nervioso gestualista.

$\mathrm{Y}$ en esto último conviene detenerse someramente. La paciencia constructora empleada en Nuevo mundo Orinoco dio paso, con el devenir de la palabra poética, a un discurso como más urgido, más gestual, más terminal, más cercano al precipicio. Si antes el interés muy marcado estuvo enfocado en la elaboración de un lenguaje de verso largo y suntuoso, más recientemente el lenguaje poético ha cedido espacio a la interpelación de decir, al nervio. Puestos a tejer relaciones entre códigos afines como son la expresión plástica y la poética, podría relacionarse una empresa como Nuevo mundo Orinoco con la pintura épica, con cierto muralismo, con la narración de una gesta. En sus poemarios más recientes su palabra está más cerca de un cielo de Turner o de un huracán de Jorge Pizzani o de un simbólico lienzo de Pájaro. Lo que sí es común a cualquiera de sus etapas es que su obra está tomada por su gobierno, su dictadura. Es un hombre que atiende a una voz interior. $Y$ ésta no le da tregua, es por eso un poeta a la vez enérgico y exhausto.

Es un autor y como tal su voz es intransferible. Hace poco tiempo, en una conversación telefónica, Liscano comenzó a disertar sobre su perrita. Me explicó que de tanto bajarla al jardín para que hiciera sus necesidades había logrado precisar algunos discursos de su aparato digestivo. Los perros, me dijo, como sólo comen carne, pues sufren de estreñimiento y mueren jóvenes; ahora Perla come cambur, cereal, toma vino tinto. Esta anécdota es reveladora de la manera como Liscano está en el mundo. Nada le deja frío. Por todo su curiosidad insaciable se interesa. Autores así son pequeños dioses en el mejor sentido. Es decir, nada queda a la buena de Dios, todo es tejido por sus manos. No sólo su obra, sino su vida, su casa, sus costumbres, su ropa. (Hace veinte años Liscano no le encontró sentido a las solapas de los trajes. Fue donde un sastre y le ordenó tres paltoses sin solapa. Aún los usa. Son extrañísimos, les falta algo. Pareciera que quien los lleva es médico o sacerdote de una secta novísima.)

El impetuoso gobierno que el poeta ejerce sobre sus cosas es el mismo que somete a su poesía y a su palabra ensayística. Su originalísima visión del mundo encuentra expresión en sus ensayos. Basta con citar su interpretación de la vida y obra del Che Guevara para aceptar lo que digo. Su libro El horror por la historia alberga este extraño texto que tiene el poder de arrojar luz sobre una zona oscura. Ésta es quizás la imagen más ajustada que produce Liscano cuando ensaya: arroja luz en los recodos sobre los que antes nadie había enfocado con su linterna. El ensayista es un minero que busca y alumbra.

Pero no es la imagen del minero la que más me gusta para centrar la obra literaria de Liscano. El día que lo conocí tendría yo diez y ocho años o menos y fui a su oficina en Monte Ávila Editores. La conversación transcurrió rápido y en medio del mayor desasosiego para mí. El poeta estuvo preciso y correcto. Mi inquietud provenía de un permanente ruido como de tambor que ocurría mientras hablábamos. Al rato descubrí que eran los pies de Liscano moviéndose a toda velocidad y topándose con la madera del escritorio. Eran como unas hélices que fungían como propiciadoras y estabilizadoras del viaje. Su 
imagen es la del nadador que se ve íntegro flotando boca arriba pero que para lograrlo le da a sus pies y sus manos todo el movimiento posible. Así es Liscano: moverse para mantenerse y avanzar. Nunca la orilla, nunca el nicho. Siempre la duda, la revisión, la inteligencia. 
